Aletria, Belo Horizonte, v. 30, n. 2, p. 17-38, 2020

(c) (1)

\title{
Literatura e resistência em Avalovara, de Osman Lins
}

\section{Literature and Resistance in Avalovara, by Osman Lins}

\section{Raul Gomes da Silva}

Universidade Federal de Mato Grosso do Sul (UFMS), Pioneiros, Mato Grosso do

Sul / Brasil

raul.avlis@gmail.com

http://orcid.org/0000-0001-6557-4193

\section{Ramiro Giroldo}

Universidade Federal de Mato Grosso do Sul (UFMS), Pioneiros, Mato Grosso do Sul / Brasil

r_giroldo@yahoo.com.br

http://orcid.org/0000-0001-9037-4310

Resumo: $\mathrm{O}$ texto discute a configuração da personagem reconhecida apenas pelo símbolo , do romance Avalovara, de Osman Lins. Propõe que a personagem pode ser lida como uma confluência de diferentes sentidos abertos para o infinito e, também, como uma alegoria da própria literatura de resistência - no caso em pauta, resistência contra a ditadura militar brasileira. As reflexões sobre violência e autoritarismo de Hannah Arendt são trazidas à tona no decorrer da investigação, bem como os apontamentos de Antoine Compagnon sobre o potencial que a literatura tem de se voltar contra a opressão. Em seu percurso argumentativo, o texto ainda se ampara em proposições de, entre outros, Maria Aracy Bonfim e Elizabeth Hazin, no que cabe ao feitio da personagem em pauta; além de Jaime Ginzburg, acerca das marcas que a violência deixa na tessitura literária. Palavras-chave: Literatura Brasileira; Osman Lins; Avalovara; violência; resistência. 


\begin{abstract}
The paper discusses the character known only by the symbol $\lessdot$, from the novel Avalovara by Osman Lins. It proposes that the character can be read as a confluence of different meanings which open to infinity and can also be read as an allegory of the resistance literature itself - in this case, resistance against the Brazilian military dictatorship. The notions of violence and authoritarianism proposed by Hannah Arendt are brought to light throughout the discussion, as well as Antoine Compagnon's remarks about the potential of literature to turn against oppression. In its argumentative course, the paper also discusses propositions by, among others, Maria Aracy Bonfim and Elizabeth Hazin, about the features of the character in question; and Jaime Ginzburg, about the marks that violence leaves on Literature.
\end{abstract}

Keywords: Brazilian Literature; Osman Lins; Avalovara; violence; resistance.

\title{
Alegoria da criação
}

Reconhecida apenas por um sinal gráfico, a personagem $\odot$, do romance Avalovara, de Osman Lins, é geralmente definida como inominada, porque não há outra forma de identificá-la senão pela figura geométrica. Essa indefinição nominal revela a impossibilidade de delimitar não só a identidade, mas também os sentidos de seu corpo, que se abrem para a multiplicidade de significações: "o corpo dela é o conteúdo, o texto total, todos os textos, todas as palavras, e por isso provavelmente não convém que seja nomeada. Ela precisa de liberdade para significar e para nomear as coisas" (BONFIM, 2014, p. 62).

Questionar o sentido do mundo por meio de uma linguagem simbólica não significa, necessariamente, "representar um mundo conhecido, mas propiciar as condições de cognoscibilidade daquilo que é representado" (HAZIN, 2010, p. 48). Umberto Eco (1991, p. 196) nos recorda que o símbolo pode ser compreendido como "um sistema de metáforas ininterruptas", como um jogo de reconhecimento entre duas partes que se reúnem para reconstituir a plenitude de uma unidade de significação:

simbólica é a atividade pela qual o homem explica a complexidade da experiência, organizando-a em estruturas de conteúdo a que correspondem sistemas de expressão. O simbólico não só permite 'nomear' a experiência mas também organizá-la e, portanto, constituí-la como tal, tornando-a pensável e comunicável. (ECO, 1991, p. 201). 
A atividade simbólica que envolve $๔$ expressa tanto a complexidade de suas experiências quanto a relação de outro personagem, o escritor Abel, com a própria linguagem, seu confronto com os limites da palavra e com a atividade de significação. O símbolo geométrico seria a manifestação de um conteúdo vivo que deflagra os conflitos do escritor em face do mundo das palavras, o lugar simbólico por excelência. É de acordo com tal lógica que Hazin (2010, p. 48) propõe que o símbolo geométrico é o "sinal visível de uma realidade invisível", pois ele sintetiza o encontro de Abel com o corpo de $\lessdot$, com a palavra que, ordenada, passa a adquirir sentidos - o que não significa nomear a mulher, mas fazer com que ela questione sua identidade, seu verdadeiro nome ou algo que possa distingui-la:

Sei que haverá um código, um sinal para chamar-me. Procuro descobri-lo no confuso ir e vir das coisas que me cercam. Será um som, será um odor, será uma cor, uma claridade? Por vezes, percutem um martelo, ou me deparo com a fachada de um prédio, ou vejo desenhos num muro, ou cravo as unhas na pele. Fico perguntando se alguma dessas coisas é o meu nome: o soar do martelo, a parede brilhando, os riscos no cimento, a dor que sinto. (LINS, 1973, p. 29).

Representação de uma realidade invisível, o corpo de $\odot$ sintetiza a totalidade de Avalovara, pois o símbolo transporta, "em uma imagem ou narrativa, o sentido do todo" (PAGANINE, 2014, p. 243). Nele, registra-se o encontro do criador com a criatura, porque desdobra a própria reversibilidade do ato criativo ao evocar as contingências da criação literária, a tessitura de espaços e planos narrativos, bem como a multiplicidade de vozes que subjazem à atividade de escrita:

Gritos e palavras nadando ou revoando em mim, eu invadida por uma multidão de vozes, eu desfeita em vozes. Como se eu fosse uma escultura de areia fina e cada grão uma voz, uma palavra e suas danações. [...] Estas palavras - e outras escorregam, começam a deslocar-se das partes do meu corpo por elas nomeadas. Já não penso no meu braço como sendo braço, mas como pés ou boca; a boca chama-se umbigo ou calcanhar; o sexo chama-se olhos, depois peito, depois ombro. Entre a minha mente e o meu corpo desmembrado flutua um pequeno léxico arbitrário. (LINS, 1973, p. 136). 
O escritor é quem transforma o signo em expressão artística, enquanto atinge a unidade de significação da palavra que, elevada ao plano simbólico da linguagem, deixa de ser somente palavra para integrar uma composição expressiva da relação do artista com o mundo. $\mathrm{O}$ símbolo torna-se representação da linguagem artística no instante mesmo em que se define "como a matéria do poeta ou da obra" (TODOROV, 2013, p. 54).

Ao receber significação, a figura geométrica converte-se em linguagem, torna-se elemento simbólico da busca pela realização amorosa e literária de Abel. Da realização amorosa porque no corpo de $\odot$ fundemse as duas primeiras mulheres de Abel e, a partir de então, elas formam um todo harmônico que reflete a dimensão de seus afetos para com as mulheres, cujos corpos têm sua potência de ação aumentada em razão dos "bons encontros" com o protagonista. Da literária porque, abarcando no corpo a corporalidade das outras personagens, reúne também as reflexões temáticas de escrita que cada uma traz consigo; ela é um ser tríplice, mas ao mesmo tempo uno, pois sintetiza tanto a experiência afetiva de Abel pela escrita quanto pelas mulheres que amou no percurso de sua vida:

Serias, Roos, em tua flutuação entre o ir e o vir, uma versão mais sutil e antecipadora das oposições de Cecília? Não corresponde à claridade que é um dos teus dons - como a noite corresponde ao dia e a morte ao nascimento certa constante de negror, associada, desde o eclipse, à presença de $ఠ$ ? Além do mais, ignoro como e até que ponto, repercutes, recôndita, não sei até que ponto, nas simetrias, nos ritmos. Tendo a crer, Cecília, que a duplicidade do teu ser coberto de cifras ressurge em $\odot$, neste caso um ser tríplice, dual e uno, e também pergunto agora se não ouço, por vezes, tua voz na sua boca. Jamais diria, entretanto, serdes fragmentos ou simples tentativas inconclusas desta que, ainda não sei como, vos revive. Sendo, cada uma, absoluta e por assim dizer ilimitada, nenhuma é tudo. Íntegras, não constituem, apesar disto, realidades solitárias: na sua integridade, unem-se em um todo - soma e súmula de totalidades - não superior ou mais perfeito do que as unidades abrangidas. (LINS, 1973, p. 262).

No corpo dela estão inscritas as outras mulheres, construídas pela linguagem trabalhada pelo escritor; por isso é que o corpo de $\lessdot$ articula as 
reflexões temáticas das duas personagens anteriores, porque ele é súmula e totalidade do ato criador, simultaneamente feita de carne e verbo, "as palavras perpassam pelo seu corpo, visíveis e audíveis" (LINS, 1979, p. 176). Ela se desdobra em um processo metonímico da linguagem que espelha a si própria e a relação do protagonista com o instrumento de trabalho: a palavra que reveste seus enunciados e transfigura a experiência em discurso:

Mergulho, olhos abertos, sob o seu corpo, deslizo sob o corpo que flutua e creio ver, meio ofuscado, entre os reflexos, outro corpo: como se os reflexos das águas penetrassem-na, pontos luminosos, roxos, verdes, brancos, não simples reflexos, signos. (Letras?). (LINS, 1973, p. 62).

Ao mergulhar no corpo da mulher, Abel faz isso duplamente: como homem e escritor. No primeiro caso, trata-se de uma incursão afetiva, com vistas à realização amorosa, carnal e sexual com $๔$, a mulher a quem ama e com a qual consolida o termo de suas buscas no mundo. Além disso, essa realização está ligada à sua procura por se efetivar também como escritor e, para isso, ele terá de percorrer o corpo feito de palavras da personagem, desvendar o mundo dos signos, organizar as letras dispersas em seu corpo, construir enunciados, enfim, dar significação às coisas por meio do ordenamento do caos das palavras que estão integradas ao corpo da mulher.

Para um duplo encontro com o escritor, ela precisa se duplicar e possuir um caráter flexível, razão pela qual o segundo corpo surge aos nove anos de idade, quando ela cai no poço do elevador do Edifício Martinelli, em São Paulo. Nesse momento, ao invés da morte, ela nasce outra vez, mas agora por meio da palavra: "assim vivo, até precipitar-me para baixo no meu velocípede [...], e tudo escurece e nessa escuridão eu sou novamente formulada, eu, novamente sou parida, sim, nasço outra vez" (LINS, 1973, p. 29). Ao nascer duas vezes, uma do ponto de vista físico e a outra do simbólico e do metafórico, a mulher passa a ser identificada como um ser de "vida dúplice, duas vezes nascida, com duas infâncias, duas idades, dois corpos" (LINS, 1973, p. 22). A partir de então ela se torna o receptáculo de um signo que precisa ser compreendido, o recipiente de uma escrita espiralada, uma grafia mítica, um texto completo em si mesmo, um corpo-palavra que se une de maneira carnal e verbal ao escritor, a Abel: "ela é espantosamente carnal e viva para o leitor; mas 
também é um ente mental do escritor, uma peça do jogo palindrômico, representada simbolicamente pelo círculo fechado onde tudo começa e acaba, com seu alvo fincado no meio" (CANDIDO, 1973 apud LINS, 1973, p. 10).

Enquanto recipiente, o corpo de $\odot$ contém o artefato verbal do trabalho literário, mas também é ele próprio extensão do mundo e da vida: "o corpo dela é continente: tanto no sentido de ser aquilo que contém alguma coisa, mas também no sentido de extensão da terra, chão, solo da criação" (BONFIM, 2014, p. 62). Em "Conteúdo e continente - o corpo de ๔: poética e criação em Avalovara", Maria Aracy Bonfim propõe que o corpo dessa personagem evoca o próprio processo de construção do romance, porque tal corpo sintetizaria a via pela qual o escritor acessa o mundo, isto é, por meio da palavra.

O símbolo geométrico é uma via de autorrepresentação simbólica, porque ela é e ao mesmo tempo representa a própria materialidade linguística dos discursos que a significam e que dão a ver a sua existência no tecido ficcional. Seu corpo constitui-se tanto ao nível do enunciado quanto da enunciação dos processos da escritura; eis o porquê de ele ser formado por palavras e nele também estarem as palavras que se configuram como a estrutura elementar do próprio romance. Ela é a substância que dá forma à criação do escritor, evocando um estatuto tautológico: as representações que seu corpo põem em jogo dizem respeito a um universo de significados voltados para si mesmos, para a própria "linguagem definida como matéria do poeta ou da obra" (TODOROV, 2013, p. 54).

๔ oferece o material verbal, os signos e as palavras de que precisa Abel para a sua construção literária; ela o introduz no "mundo jubiloso", "sem ostentação e sem pudor" (LINS, 1973, p. 224) da linguagem. Contudo "não esconde seus lixos" e o insere também no universo "convulsionado, fragmentário [e] duro" da palavra, pois "recusa-se a ceder-me um corpo sem história - o que seria ceder um objeto sem ilações e neutro?" (LINS, 1973, p. 224). A mulher não oferece um corpo vazio e isento de significação histórica para o escritor. $\mathrm{O}$ corpo dela não é neutro, nele se inscrevem enunciados de resistência à violência da ditadura militar brasileira.

A história da violência do regime militar se revela na obscuridade do tenente-coronel Olavo Hayano, marido de inominada, uma figura sombria também identificada como Iólipo, ser estéril que surge no relato 
de $\odot$, mas que está diretamente ligado ao contexto político da opressão. O Iólipo é o intruso repressor da linguagem literária, que se vê ameaçada pelo discurso cerceador das forças tirânicas e violentas do militarismo; ele é a escuridão que segrega a palavra e a mantém como uma presa de guerra:

- $\mathrm{O}$ rosto que se pode ver na escuridão, completamente diverso do que se vê na claridade, é o rosto verdadeiro do Iólipo.

- Sei bem: há, tem havido outros males na terra, sempre inúmeros. A opressão, fenômeno tendente a legitimar muitos outros males e em geral os mais prósperos, reduz a palavra a uma presa de guerra, parte do território invadido. Lida o escritor, na opressão, com um bem confiscado. (LINS, 1973, p. 261).

Hayano é o Iólipo, entidade violenta que representa a força aniquiladora da atividade criativa, isto é, da união de Abel, escritor, com $\odot$, representação da literatura. Manifesta-se, nessa relação, um confronto entre a atividade crítica e reflexiva da linguagem com a corrente impositiva e violenta da opressão, uma guerra política entre as forças do autoritarismo e $\odot$, expressão viva do literário:

Questiono o meu ofício de escrever em face da opressão. Fico ouvindo a resposta que se forma no ponto mais protegido e inviolado do meu corpo. A máquina da opressão alcança-me através das paredes e da carne. Todos os seus guardas e artífices - e ela, a máquina, opera. Máquina ou cão? Não há modo algum de escapar ao seu hálito. (LINS, 1973, p. 260).

O ofício do escritor fica comprometido quando ele estabelece relações com o mundo por meio da linguagem, ainda que esta se apresente de maneira transfigurada ou dissimulada. Assim, o escritor torna-se perigoso, pois ao trabalhar a sua matéria e inseri-la na obra, ele exerce papel político por confrontar o poder e trazer à tona os discursos do corpo social.

Assentado em um plano de composição ligado à atualidade histórica, o romance Avalovara incorpora o mundo e dialoga com os fatores de historicidade do espaço em que emerge, precisamente com a história da violência militar. De maneira cifrada, o relato frio e obscuro 
da opressão irrompe no discurso de $\odot$ e na sua relação conflituosa com Hayano, figura estéril, vazia e cerceadora. Ele é a própria personificação da monstruosidade, do autoritarismo, o rosto escuro da opressão: "Hayano é um iólipo" (LINS, 1973, p. 284), um ser sombrio de natureza violenta, "nele, o rosto escuro, fora do meu alcance, é de monstro" (LINS, 1973, p. 302). A respeito dessa figura, escreve:

Diz a minha história: serei encaminhada de modo a encontrálo. A função dele é cercear, romper, demolir em mim o que está construído, tentar impor-me o seu mundo, o seu modo. Um combate prolongado. Ao mesmo tempo, não está previsto que alguém, seja quem for, obrigue-me ou induza à travessia. Tenho de ir por mim, por mim, com o ar de quem não sabia que a catástrofe é certa e como se movessem-me esperanças. Eu, um cofre ataviado e a certeza no fundo uma ampola de veneno. Eu, amada e amante, aos olhos dos demais e aos meus próprios olhos: um cofre esmaltado com motivos florais, radioso. Mas eu, sendo o cofre, sei, sei sem clareza, sim, sem clareza, mas sei, o que trago sob as chaves - a ampola, o veneno. (LINS, 1973, p. 247).

๔ traz no corpo a ampola e o veneno, ou seja, a substância para perturbar e para negar o poder de Hayano, o seu marido, porque ela enquanto literatura também é violenta, desestrutura os discursos institucionalizados e rearticula novas possibilidades de vida. Seu corpo é linguagem tornada potência de resistência, de recusa e de negação ao poder e sua arbitrariedade: o literário refuta o poder porque legitimá-lo seria contribuir para o apagamento da criação artística enquanto via que propicia o alcance social e a consciência coletiva; o poder reprime e inviabiliza a literatura, pois ela deflagra seus mecanismos punitivos, sua estrutura e funcionamento. Nesse ponto, o poder não pode ser aliado da criação justamente porque ela é como um padrão de medida a partir do qual se avalia a sua gravidade e seu desenvolvimento (LINS, 1990, p. 223):

Nunca o poder pode ser aliado da criação artística. O artista é sempre um provocador de áreas de atrito, é um inovador. E o poder é estático. Não acredito em nada que o poder possa fazer pela cultura. Toda a aliança do artista com o poder é nociva para o artista. Nossos aliados somos nós mesmos. E o público é também nosso grande aliado no mundo contemporâneo. (LINS, 1979, p. 209). 
Sendo alegoria da criação e da linguagem literária, esta é entendida como potência de ação crítico-política, como exercício de reflexão, de aprendizado e de conhecimento do homem e do mundo (COMPAGNON, 2009). O corpo de ๔ se opõe às forças repressivas e autoritárias do regime militar, que se apoiam sobre um sistema de práticas institucionalizadas para reforçar discursos de ordenação e de violência.

A materialização da censura e da opressão no discurso ficcional de Avalovara situa a experiência traumática do terrorismo militar brasileiro da década de 1970, bem como desenha um quadro vivo do funcionamento da ordem repressiva do regime autoritário. No interior desse quadro, emerge a tentativa de não-legitimação da violência, pois legitimá-la corresponderia a uma recusa ao diálogo, à consciência da coletividade e da vida social:

A opressão, se instaurada como norma e ainda mais quando se manifesta com instrumentos precisos - quase sempre revestidos de uma moral: uma réplica da gravidade no mundo físico. Infiltra-se nos ossos e invade tudo. Infecciona o mundo. Infecciona o mundo, eu disse? Sim, isto. Uma doença. (LINS, 1973, p. 221).

Se institucionalizada, a opressão tende a cercear a atividade literária e a invalidar a sua capacidade de libertar "os indivíduos de sua sujeição às autoridades" (COMPAGNON, 2009, p. 33). A literatura, escreveu Compagnon (2009, p. 34), tem "o poder de nos fazer escapar das forças de alienação ou de opressão"; ela é de oposição porque "tem o poder de contestar a submissão ao poder". Assim, ao se contrapor à uniformidade dos regimes bárbaros e violentos, o ato criador se vê ameaçado pelas forças tirânicas da repressão:

- Sob a opressão, os atos mais simples, comprar um selo postal ou alegrar-se, são atingidos e transformamse em núcleos de interrogações. Toda alternativa faz-se dilemática e nenhuma opção pode desconhecer isto. Mais: mesmo sendo a opressão um fenômeno brutal, o peso e o significado dos atos, na sua vigência, crescem na medida em que abrangem o domínio do espírito. Segue-se que o ato criador é particularmente exposto a tal emergência. (LINS, 1973, p. 303-304). 
As formas de violência impostas pelo regime militar operam ao nível da indiferença ao sofrimento humano, porque têm em vista a validação das práticas traumáticas de tortura e de repressão. Quando isso acontece, trata-se, nas palavras de Ginzburg (2010, p. 15), de uma "ausência de ética, de indiferença com relação à dor e ao trauma coletivo", conforme se verifica no romance:

A indiferença do escritor é adequada à sua presumível elevação de espírito? Para defender a unidade, o nível e a pureza de um projeto criador, mesmo que seja um projeto regulado pela ambição de ampliar a área do visível, temse o privilégio da indiferença? Preciso ainda saber se na verdade existe a indiferença: se não é - e só isto - um disfarce da cumplicidade. Busco as respostas dentro da noite e é como se estivesse nos intestinos de um cão. A sufocação e a sujeira, por mais que procure defenderme, fazem parte de mim - de nós. Pode o espírito a tudo sobrepor-se? Posso manter-me limpo, não infeccionado, dentro das tripas do cão? Ouço: "A indiferença reflete um acordo, tácito e dúbio, com os excrementos." Não, não serei indiferente. (LINS, 1973, p. 354).

Em sentido contrário a esse, está a injustiça e o silêncio de Hayano

toda a injustiça que eu fizer terá sempre o nome de justiça. Sobram-me a força e a indiferença necessária para usar a força. A força, sem isto, nos pertence. O mais assustador é que, nesse espectro trevoso, falta uma parte do rosto. "Uma parte do rosto?" "Sim, há um vazio”. (LINS, 1973, p. 352, grifos do autor).

Indiferente à repressão militar, silencia diante da violência e do autoritarismo praticados no período ditatorial, negligenciando a vida e a livre manifestação do pensamento.

Para Hannah Arendt (1979), esse tipo de autoritarismo é um princípio comum às ditaduras militares e aos sistemas de guerras, que têm em sua gênese estruturas hierárquicas de poder absoluto que funcionam de forma verticalizada: "o comando é feito de cima para baixo, e a obediência absoluta, de baixo para cima" (ARENDT, 1979, p. 414). Isso faz com que o poder de comando dependa necessariamente do sistema impositivo a partir do qual atua e exerce controle sobre os corpos dos indivíduos, 
ou seja, as práticas de violência são empregadas por estruturas de poder que visam, além da punição, o reforço de seus próprios mecanismos de dominação. Há nessa relação, segundo a filósofa, uma estreita vinculação entre poder e violência:

O poder e a violência, embora sejam fenômenos distintos, geralmente apresentam-se juntos. Onde quer que se combinem, o poder é, conforme verificamos, o fator fundamental e predominante. A situação, entretanto, mostra-se totalmente diferente se os encararmos em seu estado puro - como, por exemplo, na invasão estrangeira e na ocupação. Vimos que a atual equação da violência com o poder baseia-se no fato de o governo ser ou não percebido como o domínio do homem sobre o homem através da violência. (ARENDT, 2004, p. 33).

Para Arendt, esse sistema de poder, caracterizado pelo domínio do homem sobre o homem, é comum não apenas onde há verticalização e hierarquização dos processos disciplinares e punitivos. $\mathrm{O}$ poder passa a adquirir novas configurações que assinalam o caráter não institucionalizado dos mecanismos de sujeição. Em outras palavras, a esse sistema de poder em que a hegemonia soberana é o eixo centralizador e definidor das práticas impositivas de governo e de dominação deve-se

acrescentar a mais nova e talvez a mais formidável forma desse domínio: a burocracia ou o domínio de um intrincado sistema de órgãos no qual homem algum pode ser tido como responsável, e que poderia ser chamado com muita propriedade o domínio de Ninguém. (ARENDT, 2004, p. 24).

Essa forma descentralizada de exercício do poder dificulta a identificação daqueles que exercem atos tirânicos e, consequentemente, torna mais complexa a tarefa de definir culpados, conforme Arendt:

Se, de acordo com o pensamento político, identificarmos a tirania como um tipo de governo que não responde por seus próprios atos, o domínio de Ninguém é claramente o mais tirânico de todos, uma vez que não existe alguém a quem se possa solicitar que preste conta por aquilo que está sendo feito. E esse estado de coisas tornando impossível a localização da responsabilidade e a identificação do 
inimigo, que figura entre as mais potentes causas da inquietação rebelde que reina em todo o mundo, de sua natureza caótica, e de sua perigosa tendência a descontrolar-se. (ARENDT, 2004, p. 24).

Se o poder apresenta-se como "um fim em si mesmo", não necessitando obrigatoriamente de um aparelhamento de Estado para se efetivar na vida social, faz-se necessária a criação de estratégias de resistências a essas novas relações de poder, que têm em suas gêneses os princípios de violência, de imposição e de obediência ao arbitrário e às forças tirânicas da repressão. A literatura e a crítica literária podem ser vias para operar modos de resistência a essas novas relações de poder e de censura, por meio da consciência do passado e da memória da dor e do sofrimento causados pela ditadura militar, de acordo com os apontamentos de Ginzburg:

A memória da ditadura militar brasileira se impõe como um problema fundamental para a crítica literária. Em um país em que as heranças conservadoras são monumentais, e as dificuldades para esclarecer o passado são consolidadas e reforçadas, o papel de escritores, cineastas, músicos, artistas plásticos, atores e dançarinos pode corresponder a uma necessidade histórica. Enquanto instituições e arquivos ainda encerram mistérios fundamentais sobre o passado recente, o pensamento criativo pode procurar modos de mediar o contato da sociedade consigo mesma, trazendo consciência responsável a respeito do que ocorreu. (GINZBURG, 2010, p. 241).

Ao situar o romance no contexto repressivo da ditadura militar brasileira, isto é, em um universo totalmente contrário à manifestação de novas ideias e à produção de conhecimento, Osman Lins traça um movimento de resistência ao poder que penetra na trama da sociedade, desnudando a violência do regime militar tanto no seu discurso crítico quanto no ficcional. Tem-se nesse movimento uma tentativa de trazer à tona a experiência traumática da violência e a memória de um período da história brasileira marcado pelo cerceamento da atividade artística:

A censura me entristece e me preocupa. Desde que haja interferência na criação artística, existe também interferência na perfeita captação dos fragmentos 
do mundo. A censura é uma apropriação indébita. E depredadora, porque não utiliza aquilo de que se apropriou nem permite que outros tomem conhecimento. A comunidade é espoliada porque não recebeu intacto o que era do seu direito receber. (LINS, 1979, p. 209).

O exercício da violência, no romance Avalovara, está ligado ao poder e às práticas de regulação da vida de $\lessdot$, alegoria da literatura. Por meio da interdição e repressão do corpo de ๔, o tenente-coronel demonstra seu discurso impositivo e autoritário, este que o denuncia como controlador ao mesmo tempo em que revela o vazio e a esterilidade que o cercam. Visto sob essa ótica, $\odot$, artefato verbal e imagem da criação, converte-se em figura vilipendiada pelo discurso violento da ditadura militar, que cerceia o seu corpo porque ele é a própria representação do mundo e da vida:

Evoca o corpo de $\lessdot$ esse artefato irradiante. Nele, sem que eu realmente possa saber como, capto um vozerio difuso; e a significação do vozerio ultrapassa a de um discurso, consistindo numa espécie de entrelaçamento próximo do caos. Domina-me a convicção de que, no centro do seu corpo, imagem de uma escrita esquecida - esta, por sua vez, imagem do mundo e da sua contemplação -, pode-se entrever, entrever apenas, um nexo possível, sem leis e ainda remoto. (LINS, 1973, p. 328).

De maneira emblemática, a trajetória da personagem $\odot$, especialmente a trajetória da escrita de seu corpo, evoca: a relação entre literatura e história; o poder e a violência; o mal-estar e a tensão gerados pelo regime militar; o confronto da criação com a opressão; a busca por formas de resistências a um contexto hostil e adverso. Traços que se materializam na experiência corporal dessa mulher e implicam uma tentativa de diminuição de sua potência e de sua capacidade de resistir às dimensões traumáticas da repressão.

A memória dessa resistência manifesta-se em Avalovara na forma de um relato sensível, mas ao mesmo tempo angustiante, das forças tirânicas da repressão, alegorizadas por meio de uma reflexão progressiva acerca dos textos realizados sob a aura de ambientes inóspitos e opressivos. Por meio da linguagem alegórica, Avalovara traz à cena as dificuldades enfrentadas pelo artista diante de um contexto contrário ao 
desenvolvimento do ato criador, principalmente da dificuldade em fazer com que a escrita não se embeba do discurso do dominador e seja, ao contrário, instrumento de desequilíbrio e denúncia do sofrimento e da dor provocados pelo regime.

๔ é imagem do pensamento democrático, da liberdade e da abertura para o diálogo que a claridade de seu corpo possibilita: "perpassa na sua carne e ossos, fugitiva, uma transparência idêntica à das uvas claras, no âmago das quais entrevemos a sombra das sementes" (LINS, 1973, p. 259). Essa claridade é a luz que clareia o ambiente sombrio e inóspito do regime militar, é a possibilidade de resistência à opressão por meio da literatura, a semente, o fermento para o reinício, a via através da qual o escritor vislumbra a liberdade, visto que ela representa a literatura e a criação.

Tal representação ganha força por meio de uma outra alegoria, também construída em torno das significações do corpo: o pássaro chamado Avalovara. Esse pássaro habita o corpo da personagem e é feito de pequenos pássaros: "o Avalovara [...] é um ser composto, feito de pássaros miúdos como abelhas. Pássaro e nuvem de pássaro" (LINS, 1973, p. 282). A respeito desse pássaro no romance, Osman Lins declarou:

Esse pássaro, além de outras coisas, é uma imagem do romance. Não desse romance apenas. E sim do romance em geral. O romance aglutina narrativas menores, breves unidades temáticas, pássaros miúdos. Não é o meu romance que é assim. Qualquer romance é isso. E eu já lembrei há pouco que o Avalovara é em certo sentido uma alegoria do romance. (LINS, 1979, p. 180).

Ao fim e ao cabo, o pássaro simboliza o próprio romance de Lins, igualmente nomeado como Avalovara e formado por um conjunto de oito micronarrativas (ou oito capítulos) que se ligam e se entrecruzam formando a totalidade harmônica da obra. A violência que se opera contra o corpo de $\lessdot$, portanto, decorre, em realidade, do fato de ela ser depositária do pássaro Avalovara que há no centro do seu corpo, ou seja, do próprio Avalovara como obra literária ligada às dimensões políticas, sociais e históricas de seu tempo. A violência e a tentativa de barrar a potência do corpo da mulher se dão justamente com o objetivo de inviabilizar o voo do pássaro pelas vastidões do mundo, isto é, o alcance da palavra, da escrita e da literatura em seus diferentes níveis. 


\section{O pássaro Avalovara}

A ideia de ad infinitum proposta por Avalovara está espalhada por toda a obra, como propõem as peças palindrômicas da espiral a partir das quais o romance desenvolve seu percurso e como propõe, inclusive, o pássaro cujo nome é o mesmo do romance: "Ataviado com todas as cores dos pavões, o Avalovara lembra um manuscrito iluminado. Nele, quase é possível ler" (LINS, 1973, p. 281). Essa natureza circular do texto insere o leitor no princípio aleatório da narrativa e permite a sua entrada in media res na textualidade da obra: o texto possui um caráter labiríntico que se estende ao infinito porque é operacionalizado por meio de uma construção metaficcional que possibilita a espacialização de sua própria linguagem e história.

É por essa razão que, quando o leitor chegar ao final do texto, estará retomando o próprio início e vice-versa. A sala do apartamento de $๘$, que, em verdade, é o espaço para onde converge o fim do texto, o ponto $\mathrm{N}$ da espiral, é a mesma que abre as portas da narrativa e inaugura o relato. Conforme o próprio protagonista nos dirá na primeira página do romance: "no espaço ainda obscuro da sala, nesta espécie de limbo ou de hora noturna formada pelas cortinas grossas, vejo apenas o halo do rosto que as órbitas ardentes parecem iluminar" (LINS, 1973, p. 13).

Elizabeth Hazin (2014, p. 106), em texto publicado no livro Palindromia, esclareceu que essa linguagem palindrômica e espelhada do autor é construída por meio de um "método de escritura que desponta como estratégia textual". Tal método funciona, segundo a pesquisadora, como "operadores do texto, na medida em que ajudam a pensar o texto ao tempo em que fazem o texto se pensar a si próprio, sintetizando em torno de si densos conjuntos de significado" (HAZIN, 2014, p. 107). Ela acrescenta ainda que o processo de construção literária de Osman Lins se assemelha às estratégias narrativas empregadas no texto árabe das Mil e uma noites, "mais precisamente aquela que metaficcionalmente alude ao texto como um todo, permitindo aos leitores vislumbrarem a história por trás das histórias que estão a ler" (HAZIN, 2014, p. 106). Enquanto o leitor lê a história, ele tem acesso aos seus processos de elaboração, porque, uma vez espacializada, a linguagem torna-se personagem de si mesma. De acordo com Jorge Luis Borges, quando isso acontece, tem-se um livro de caráter infinito, porque seus procedimentos de composição dão-se em movimento circular: 
eu tinha me perguntado de que maneira um livro pode ser infinito. Não conjeturei outro procedimento que o de um volume cíclico, circular. Um volume cuja última página fosse idêntica à primeira, com possibilidade de continuar infinitamente. Recordei também aquela noite que está no centro das Mil e uma Noites, quando a rainha Scherazade (por uma mágica distração do copista) põe-se a contar textualmente a história das Mil e uma Noites, com risco de chegar outra vez à noite na qual está fazendo o relato, e assim até o infinito. (BORGES, 1999, p. 48).

O diálogo com as reflexões de Borges sobre o livro levado ao infinito também é apontado por Hazin ao assinalar os elementos norteadores da escrita de Lins, os quais dão a ver, em Avalovara, a presença do que a pesquisadora chama de "figuras conceituais, porque, não sendo propriamente conceitos, possuem valor de" (HAZIN, 2014, p. 107, grifos da autora). Tais figuras são identificadas por Hazin tanto ao nível lexical quanto imagético; naquele, aponta-se, por exemplo, as palavras "emarame", "Ubatuba" e "Unicórnio" (HAZIN, 2014, p. 108), que são palavras palindrômicas assim como a frase elaborada por Loreius; "as duas últimas palavras adquirem estatuto palindrômico de maneira inusitada, silabicamente: ubaTuba e u ni cor ni u (a última delas devendo ser considerada foneticamente)" (HAZIN, 2014, p. 108). Por sua vez, a figura geométrica pode ser compreendida como um exemplo de imagem ao nível das figuras conceituais propostas por Hazin, visto que os sentidos atribuídos a ela constroem um conjunto de significados que correspondem a um pensamento próprio do universo textual de Lins, tornando-se uma chave de leitura dos diversos planos do romance: "o estrutural, o sintático, o lexical, o imagético" (HAZIN, 2014, p. 108). A permanência dessas figuras é importante porque, engendrando densas significações, desvendam e auxiliam no processo de construção e de apreensão dos diferentes níveis do texto osmaniano.

A imagem dessa figura é ampliada pelos diversos rearranjos do corpo de $\odot$, que se desdobra ora em físico e carnal, ora em material, simbólico, alegórico, metafórico etc. O pássaro Avalovara, que surge ainda na adolescência da mulher, estaria relacionado ao sentido alegórico do seu corpo. O pássaro é uma alegoria do próprio romance que o leitor tem em mãos, uma alegoria do Avalovara pronto, concluído, da obra conquistada. Mas ele é, também, alegoria do texto exposto ao contexto 
opressivo do regime militar e às práticas de repressão inerentes aos sistemas totalitários:

$\mathrm{Eu}[๔]$ continuo a falar, dentro de mim, dos passeios com Inácio Gabriel, anunciador, antecipador deste homem a quem me entrego e amo, da adolescência vivida e revivida, dos nomes de pessoas que pesam em meu destino, dos enganos, da bala disparada e cravada no meu peito, da minha morte e, reiteradamente, do iólipo, o qual ninguém conhece e o qual descrevo com minúcias, sem nada entender e sem saber (saber como?) que um dia o encontro. A ele, um iólipo. Iólipo? (LINS, 1973, p. 114).

Quando o escritor conquista a obra e atinge o cerne da expressão, tanto ele quanto sua criação convertem-se em ameaça para o sistema militar, porque deflagram os mecanismos violentos postos em operação pelo regime. ๔ é, simultaneamente, súmula do pássaro Avalovara e do romance de Osman Lins, pois é representação do literário perseguido e censurado pelo poder militar. É ainda por tal poder temida, já que é instrumento de resistência e de luta contra o sistema opressivo.

Não se pode esquecer que o momento histórico de composição do romance é justamente um período de ditatura, o que pode apontar a escrita de Osman Lins como uma micropolítica da resistência pela diferença, um instrumento de diferenciação em face da barbárie. O escritor está a falar em seu texto sobre resistência. "A resistência consistiria em embarcar nos processos de diferenciação de todos esses modelos [...]" (GUATTARI; ROLNIK, 1996, p. 81). O corpo da mulher, morada do pássaro, se inscreve como corporalidade que engendra processos de resistência aos modelos de violência e repressão, razão pela qual ele será atingido pelo governo militar - a mulher será assassinada pelo marido, a mais autêntica representação da ditadura no romance:

O Avalovara renasce no betume, livre da mudez e da imobilidade a que está condenado desde a hora em que Olavo Hayano me estupra com sua glande fria; emplumase o esqueleto de fóssil incrustado na minha carne (como, na memória, um nome), desata-se, leve, com seus ossos de ar, fogo de artifício rompendo as trevas compactas. Abro os olhos: Avalovara, o pássaro do meu contentamento. (LINS, 1973, p. 279-280). 
O romance nasce no meio da sujeira da ditadura militar, resiste à violência e se propaga como objeto vilipendiado justamente por operacionalizar, por meio de seus diversos níveis narratológicos, uma crítica ao regime. Segundo a ditadura militar, o livro é um objeto nefasto e indesejado, que cresce e se espalha por áreas institucionalizadas, desequilibrando o solo de regiões opressivas, causando danos à uniformidade dos sistemas estabilizados; à semelhança de uma erva daninha que surge "exclusivamente entre os grandes espaços não cultivados. Ela preenche os vazios. Ela cresce entre, e no meio das outras coisas" (DELEUZE; GUATTARI, 2011, p. 40). Como a erva daninha, o romance se desenvolve não por meio de raiz (posto que a erva cresce por dispersão), mas se expande por ramificações em inúmeras direções, conectando as micropolíticas, desterritorializando áreas e criando uma cartografia móvel dos discursos de resistência.

Para Deleuze e Guattari, a literatura de resistência, aquela que se firma como potência de intervenção crítica e política, pode ser comparada à erva daninha, porque esse tipo de literatura, assim como a erva que nasce para desequilibrar o solo, não bem-vinda, cresce em ambientes inóspitos (no betume) para pôr em suspensão a propagação do ódio, da violência e da censura. A erva não precisa ser convidada para surgir na terra, ela simplesmente brota com a função unicamente de perturbar e desequilibrar aquilo que está posto, levantado e construído. Assim também é a literatura de resistência, que se impõe como instrumento de enfrentamento e de combate ao fascismo, aos governos autocráticos e ditadores, os quais ceifam a natureza mesma da vida, da existência humana naquilo que há de belo e potente. ๔ tem consciência disso, sabe que seu corpo é instrumento de oposição à tirania: "Aspiro o vazio de Hayano como quem aspira um odor de ossos" (LINS, 1973, p. 182). Só por meio dessa consciência é que a mulher consegue compreender as dimensões do mal e as interferências que a repressão impõe não somente a si própria, mas a todo o corpo social:

Tornamo-nos, sob a opressão, piores do que éramos. Na melhor das hipóteses, somos assassinados ou aprendemos a amar a violência. Apenas, não nos cabe do todo, sob a opressão, o peso dos nossos atos: a posição do opressor não é sem ônus. Por mais que acuse, e ele necessita de acusar, pois detém o privilégio das sentenças e das execuções, arca - embora se recuse a isto - com as respostas dos demais. 
Ele é o culpado, se investe contra mim; se eu próprio me destruo, a culpa é sua; se eu o mato, o culpado ainda é ele: assassino de si mesmo. (LINS, 1973, p. 364-365).

Na textualidade do romance Avalovara, $\odot$ apresenta-se como uma figura emblemática, porque nela reverberam níveis discursivos vários: 0 metalinguístico, o literário, o crítico, o político, enfim, ela desdobra um conjunto de enunciados que ampliam sua função na obra e redirecionam seu lugar enunciativo. Afinal, a materialidade de seu corpo é o ponto de partida para uma articulação entre a linguagem, objeto do trabalho de um escritor em guerra "consigo próprio, com as palavras, com as correntes literárias e triunfantes, com o editor, com a estrutura social etc." (LINS, 1979, p. 145), e os fatos históricos e sociais brasileiros por ela incorporados - razão pela qual o corpo é reprimido e censurado.

A narrativa de Lins mostra-se atenta aos problemas de seu tempo e, assim, constitui-se como objeto de recusa e de protesto contra o exercício do autoritarismo. Dessa forma, Osman Lins, por ter percebido o "escuro do seu tempo como algo que lhe concerne e não cessa de interpelá-lo" (AGAMBEN, 2009, p. 64), foi um escritor contemporâneo em relação ao seu tempo, porque soube ver as sombras que o cercavam, sem criar qualquer vínculo com o poder, mas confrontando-o por meio de seu trabalho com a palavra. $\odot$ e Abel são a força dessa expressão, são a combinação do trabalho de Lins e de seu interesse por alinhavar em sua escrita as relações entre o escritor, a literatura e a vida. É a partir da relação de Abel com a mulher que se esboça no texto a cartografia de um mapa para o qual convergem o fim e o início das coisas:

Fim e início. $ఠ$ e eu, frente a frente, lado a lado, dorso contra dorso. O Sol, a Lua, a Interferência, a Treva, a Convergência, o Percurso, a Cadência, o Equilíbrio. Dorso contra Dorso, lado a lado, face a face, os braços em T. Onde? Surgem, ao tempo de Carlos Magno, os mapas trocóides e com eles vão ao mar os navegantes. As águas, nesses mapas, são desenhadas como um T sobre o O: um T sobre a Terra. Seremos, nós, como os braços abertos, T ante $\mathrm{T}$, rodeados pelo mundo, um mapa? Que águas seriam então em nós evocadas com seus peixes? (LINS, 1973, p. 314).

Aí estão, lado a lado, dorso contra dorso, para serem assassinados pelo poder militar, para findar um percurso, mas também para iniciar 
um outro, o da palavra construída e alcançada, para existirem enquanto linguagem, pois, mesmo mortos, fundem-se no tapete do apartamento de ๔, uma "representação do Éden, uma espécie de beleza solene e vagamente aterradora" (LINS, 1973, p. 397). A mulher e o escritor são mortos, mas já terão alcançado voos maiores, porque, concluída a narrativa, transcendem os limites materiais de seus corpos ao atingirem a unidade do texto, o cerne da palavra. Convertem-se em linguagem e nela fazem morada:

Aqui estamos, havemos de morrer mas ainda estamos vivos e afinal a vida, longa ou breve, dura apenas um dia, ninguém vive dois dias, ninguém, importa que haja nesse dia uma hora, um minuto, um instante que ilumine o resto e fure os socavões, os sótãos, eu te amo, com garras e com dentes, ama-me. Vem a penúria? A desolação dos tempos? Vem o Apocalipse? As bestas flageladoras? Venham. Estamos enlaçados. Vivos estamos”. (LINS, 1973, p. 321).

Findo o percurso, o alcance das buscas, a realização do texto e a consagração dos amantes, ambos transcendem os limiares históricos, transformados em personagens de uma narrativa mítica cuja temática se centra no encontro com o divino e o celestial: "Acreditam? Estou sentindo um perfume de terra. Vou ser recebida! Vou ser recebida por Deus!" (LINS, 1973, p. 342). Uma busca pelas origens da natureza humana, pelo princípio genealógico do homem que procura se reconectar com o sagrado, o Paraíso Perdido, o Jardim do Eden: "Estamos abraçados sobre um quadro fantástico e engendrado na Beatitude [...], acrescentando ao espaço do jardim uma qualidade arbitrária e vagamente celeste. $\mathrm{O}$ tapete é o Paraíso [...]" (LINS, 1973, p. 356-357). Os corpos dos amantes atingem outro estado de significação: agora revestidos de transcendência e consagrados ao rito, unem-se à espiral para ser e existir no movimento (des)contínuo do tempo; a narração terá atingido o cerne da espiral, a sua natureza circular e reversível, propiciando a construção de uma cosmogênese humana ao articular o fim da matéria e o início do ser na temporalidade mitológica, que corresponde à ideia reiterada da criação da vida e ao encontro com a imanência do sagrado: o casal protagoniza uma fábula de queda e expulsão, mas a chegada ao Paraíso aponta sinais de redenção. 


\section{Referências}

AGAMBEN, Giorgio. O que é o contemporâneo e outros ensaios. Tradução de Vinícius Nicastro Honesko. Chapecó: Argos, 2009.

ARENDT, Hannah. Origens do totalitarismo. [S. l.: s. n.], 1979. Disponível em: http://www.dhnet.org.br/direitos/anthist/marcos/hdh_ arendt_origens_totalitarismo.pdf. Acesso em: 22 jun. 2019.

ARENDT, Hannah. Sobre a violência. Tradução de André Duarte. Rio de Janeiro: Relume Dumará, 2004.

BONFIM, Maria Aracy. Conteúdo e continente - o corpo de ๔: poética e criação em Avalovara. In: HAZIN, Elizabeth (org.). Linscritura: limiares da escrita osmaniana. Rio de Janeiro: Vieira \& Lent: CNPq, 2014. p. 61-69.

BORGES, Jorge Luis. O jardim das veredas que se bifurcam. In:

Ficções. Tradução de Carlos Nejar e Maria Carolina de Araújo. São Paulo: Globo, 1999. p. 44-51.

CANDIDO, Antonio. Prefácio. In: LINS, Osman. Avalovara. São Paulo: Edições Melhoramentos, 1973. p. 9-11.

COMPAGNON, Antoine. Literatura para quê?. Tradução de Laura Taddei Brandini. Belo Horizonte: Editora UFMG, 2009.

DELEUZE, Gilles. GUATTARI, Félix. Mil Platôs: capitalismo e esquizofrenia 2. Tradução de Ana Lúcia de Oliveira, Ana Guerra Neto e Célia Pinto Costa. São Paulo: Editora 34, 2011. v. 1.

ECO, Umberto. Semiótica e filosofia da linguagem. Tradução de Mariarosaria Fabris e José Luiz Fiorin. São Paulo: Ática, 1991.

GINZBURG, Jaime. Crítica em tempos de violência. 2010. 300f. Tese (Livre Docência em Literatura Brasileira) - Faculdade de Filosofia, Letras e Ciências Humanas, Universidade de São Paulo, São Paulo, 2010.

GUATTARI, Felix; ROLNIK, Suley. Micropolítica: cartografias do desejo. 4. ed. Petrópolis: Vozes, 1996.

HAZIN, Elizabeth. Como um segredo de um cofre: reflexões acerca de uma personagem feminina em Osman Lins. Revista Angulo/Caderno do Centro Cultural Teresa D'Ávila, Lorena (SP), n. 121/122, p. 47-51, abr./ 
set. 2010. Disponível em: http://www.unifatea.edu.br/seer/index.php/ angulo/article/viewFile/737/505. Acesso em: 19 ago. 2018.

HAZIN, Elizabeth. Palindromia. In: HAZIN, Elizabeth; BARRETO, Francismar Ramírez; BONFIM, Maria Aracy (org.). Palindromia. Brasília: Siglaviva, 2014. p. 105-115.

LINS, Osman. Avalovara. São Paulo: Edições Melhoramentos, 1973.

LINS, Osman. Evangelho na Taba: novos problemas inculturais brasileiros. São Paulo: Summus, 1979.

LINS, Ronaldo Lima. Violência e literatura. Rio de Janeiro: Tempo Brasileiro, 1990.

PAGANINE, Joseana. A poética osmaniana: entre a alegoria e o símbolo. In: HAZIN, Elizabeth (org.). Linscritura: limiares da escrita osmaniana. Rio de Janeiro: Vieira \& Lent; CNPq, 2014. p. 239-255.

TODOROV, Tzvetan. Linguagem e literatura. In: . As estruturas da narrativa. Tradução de Leyla Perrone-Moisés. São Paulo: Perspectiva, 2013. p. 53-65.

Recebido em: 31 de outubro de 2019. Aprovado em: 22 de abril de 2020. 